\title{
p53 gene alterations and protein accumulation in colorectal cancer
}

\author{
R Bertorelle, G Esposito, C Belluco, L Bonaldi, A Del Mistro, D Nitti, M Lise, \\ L Chieco-Bianchi
}

\begin{abstract}
Aim-To correlate immunohistochemical staining with single strand conformation polymorphism (SSCP) analysis of the p53 gene in colorectal cancer in order to understand how the findings provided by the two techniques complement each other in defining $\mathrm{p} 53$ functional status.

Methods-Frozen tumour tissue from 94 patients with colorectal cancer was studied for p53 protein accumulation and gene mutations. Accumulation of p53 protein was detected by immunohistochemistry using PAb1801 and BP53-12-1 monoclonal antibodies. The findings were then compared with SSCP analysis of exons 5 to 8 of the p53 gene. All cases with a positive result by SSCP analysis were confirmed by sequencing.
\end{abstract}

Results-Nuclear staining was observed in $51(54 \cdot 2 \%)$ cases. SSCP analysis of the DNA amplified by PCR revealed that the electrophoretic pattern had shifted in $\mathbf{3 0}$ cases; sequence analysis confirmed the occurrence of a mutation in 29 cases and of a polymorphism in one. In 27 cases both assays gave a positive result, and in 40 both were negative; therefore, concordance between PCR-SSCP and immunohistochemistry was seen in $72 \%$ of cases. Conclusion-The data indicate that positive immunostaining corresponds with the presence of a mutation in most, but not all, cases studied; other mechanisms could be responsible for stabilisation and accumulation of $p 53$ protein in the nucleus. Nonsense mutations which do not confer stability on the protein will not be detected by immunohistochemistry and false negative results can also occur with SSCP analysis.

(f Clin Pathol: Mol Pathol 1996;49:M85-M90)

Keywords: p53, colorectal cancer, immunohistochemistry, PCR-SSCP.

Several genetic alterations have been shown to play a significant role in tumorigenesis. By and large, the most frequently observed molecular changes occur in the p53 gene. ${ }^{1}$ The $\mathrm{p} 53$ gene encodes a protein involved in control of the cell cycle, which is capable of binding to DNA and acts as a negative regulator in the cell's response to damaged DNA. ${ }^{2}$

Functional alteration of p53 protein can occur through several mechanisms: point mutations, deletions, and rearrangements in the p53 gene; binding with viral proteins (for example, SV40 $T$ antigen, adenovirus E1b, papillomavirus E6); binding with cellular proteins (for example, mdm-2 oncoprotein, heat shock proteins); and oligomerisation. ${ }^{3}$ Wild-type p53 protein has a very short half-life, whereas mutated p53 is stable and can accumulate at high concentrations in the nuclei of tumour cells. As a consequence, immunohistochemical staining with specific antibodies can be used to detect mutant p53 protein. However, p53 overexpression can also reflect the accumulation of wild-type protein that has been stabilised via a mechanism other than mutation-for example, by binding with SV40 T antigen, which greatly increases the half-life of the protein. ${ }^{4}$

The detection of $\mathrm{p} 53$ protein by immunohistochemistry is simple, can be applied to both frozen and archival tissues, and has been used extensively in the study of tumour pathology; correlation of immunohistochemical findings with anatomopathological variables and clinical outcome revealed that accumulation of p53 protein in tumour cells is of prognostic importance. As pointed out by Wynford-Thomas ${ }^{5}$ and Hall and Lane, ${ }^{6}$ immunohistochemical assessment of p53 should be carried out in a standardised manner to enable comparison of results obtained in different laboratories and, in this context, quantitation of p53 overexpression is particularly important. Antigen detection is influenced by many variables, such as the absolute amount of the protein, the characteristics of the antibody (sensitivity, specificity, concentration, duration of incubation), the type of material under study (frozen versus fixed/embedded tissue), and the effects of fixation and other treatments. Detecting the precise alteration occurring at the genetic level is much more laborious and costly. The most widely used molecular approach is single strand conformation polymorphism (SSCP) analysis of DNA fragments amplified by $\mathrm{PCR},{ }^{7}$ with subsequent sequence analysis. The sensitivity of SSCP is influenced by the experimental conditions, and by the length of the amplified fragment under study.

A number of investigations have addressed the relation between $\mathrm{p} 53$ protein accumulation and $\mathrm{p} 53$ gene alterations in different tumour types. ${ }^{8-17}$ Several antibodies were used in these analyses, PAb 1801 and DO-7 being the most common. The SSCP technique utilised by various workers is based mainly on the classic method of Orita et $a l^{7}$ with modifications in the percentages of glycerol or acrylamide used. The concordance rates between immuno- 
histochemistry and SSCP (both negative or both positive) fall within a relatively wide range ( 50 to $86 \%$ ), but this probably depends on differences both in methodology and tumour type.

The present study correlates immunohistochemical staining of $\mathrm{p} 53$ protein with SSCP analysis of DNA amplified by PCR.

\section{Methods}

ACCUMULATION OF P53 PROTEIN

Frozen sections of 94 colorectal carcinomas were stained, as described previously, ${ }^{18}$ with two monoclonal antibodies that react with both the wild-type and mutant forms of human p53 protein; PAb 1801 (Oncogene Science, Uniondale, New York, USA) recognises an epitope between amino acids 32 and $79,{ }^{19}$ and BP5312-1 (Biogenex, San Ramon, California, USA) reacts with the $\mathrm{N}$-terminal region between amino acids 1 and $45 .{ }^{20}$ Briefly, sections were incubated with primary antibody overnight at $4^{\circ} \mathrm{C}$ (for PAb 1801) or for 90 minutes at room temperature (for BP53-12-1). Using 3-3' diaminobenzidine (DAB) as substrate, the avidin-biotin peroxidase complex technique was carried out as described by the manufacturer (ABC kit, Vector Laboratories, Burlingame, California, USA), and the sections were then counterstained with Mayer's haematoxylin.

Paraffin wax sections were also examined in 20 cases because few cells were stained on the frozen sections or they contained too few tumour cells. Antigen was retrieved from the formalin fixed, paraffin wax embedded material by pre-heating the tissue sections in a microwave oven. ${ }^{2122}$ The amount of tumour tissue in each biopsy specimen was evaluated on frozen sections stained with haematoxylin and eosin, and compared with the amount of normal tissue on the same slide.

Sections with nuclear staining in less than $10 \%$ of the tumour cells were regarded as negative, those with staining in $10 \%$ to $25 \%$ of cells were scored + , those with staining in $25 \%$ to $75 \%$ were scored ++ , and those with staining in over $75 \%$ were scored +++ .

\section{P53 MUTATION ANALYSIS}

Extraction of DNA

To obtain genomic DNA, sections of frozen tissue $20 \mu \mathrm{m}$ thick were digested overnight at $37^{\circ} \mathrm{C}$ with proteinase $\mathrm{K}$ in TNE buffer $(10 \mathrm{mM}$

Table 1 Comparison of reactivity of PAb 1801 and BP53-12-1 antibodies in cases with equivocal results

\begin{tabular}{|c|c|c|c|c|}
\hline \multirow[b]{3}{*}{ Case } & \multicolumn{4}{|c|}{ Immunohistochemistry } \\
\hline & \multicolumn{2}{|c|}{$P A b 1801$} & \multicolumn{2}{|c|}{ BP53-12-1 } \\
\hline & Frozen & Paraffin & Frozen & Paraffin \\
\hline $\begin{array}{l}\text { B.I. } \\
\text { B.A. } \\
\text { P.M.V. } \\
\text { C.E. } \\
\text { V.I. } \\
\text { S.U. }\end{array}$ & $\begin{array}{l}- \\
- \\
- \\
- \\
- \\
-\end{array}$ & $\begin{array}{l}- \\
+ \\
+ \\
+ \\
++ \\
+\end{array}$ & $\begin{array}{l}++ \\
++ \\
- \\
- \\
+ \\
+++\end{array}$ & $\begin{array}{l}++ \\
+ \\
+ \\
++ \\
+++ \\
+++\end{array}$ \\
\hline
\end{tabular}

Tris, $100 \mathrm{mM} \mathrm{NaCl}, 1 \mathrm{mM}$ EDTA) and sodium dodecylsulphate, and then extracted with phenol/chloroform; DNA was precipitated with $1 / 10$ volume $3 \mathrm{M}$ sodium acetate $(\mathrm{pH} 5 \cdot 0)$ and two volumes of cold absolute ethanol $\left(-20^{\circ} \mathrm{C}\right)$, washed with $70 \%$ ethanol, air dried, and redissolved in distilled water.

In some cases DNA was extracted from formalin fixed, paraffin wax embedded material as described by Levi et $_{\text {al. }}{ }^{23}$

\section{PCR-SSCP}

p53 gene mutations were detected $b_{j}$ PCRSSCP analysis of exons 5 to 8 as described previously. ${ }^{18}$ Briefly, 25 amplification cycles were carried out in a DNA thermal cycler $90^{\circ} \mathrm{N}$, (Perkin Elmer, Norwalk, Connecticut, USA) followed by five further "hot" cycles with $1 \mu \mathrm{Ci}$ alpha ${ }^{33} \mathrm{P}$-dATP. Annealing temperatures were $60^{\circ} \mathrm{C}$ (exons 5 and 6 ), $56^{\circ} \mathrm{C}$ (exon 7) and $51^{\circ} \mathrm{C}$ (exon 8). The amplified products were denatured in formamide loading buffer $195 \%$ formamide, $20 \mathrm{mM}$ EDTA, $0.05 \%$ xylene cyanol, $0.05 \%$ bromophenol blue) and run at $30 \mathrm{~W}$ on a $6 \%$ polyacrylamide gel containing $5 \%$ glycerol. The gel was then dried and exposed to $x$ ray film at $-80^{\circ} \mathrm{C}$ for 12 to 48 hours.

\section{Direct DNA sequencing}

Shifted bands were eluted from the gel, amplified by PCR incorporating a phosphorylated primer, and digested with lambda exonuclease to convert the double stranded PCR product to a single stranded form. Other reaction components were removed from the template both prior to and following digestion by using Micro Spin columns containing Sephacryl S-400 HR resin (Pharmacia Biotech, Piscataway, New Jersey, USA).

DNA was then sequenced by the Sanger dideoxy chain termination method ${ }^{24}$ using the "fmol DNA sequencing system" (Promega Corporation, Madison, Wisconsin, USA).

\section{Results}

IMMUNOHISTOCHEMISTRY

Overall, $51(54 \cdot 2 \%)$ of the 94 primary colorectal cancers exhibited positive nuclear staining with BP53-12-1; 49 (52.1\%) showed nuclear reactivity with PAb 1801 . No nuclear staining was detected in normal mucosa with either antibody. More than $90 \%$ of cells were neoplastic in 55 cases, between 50 and $90 \%$ of cells in 22 cases, and between 10 and $50 \%$ of cells in 12 cases. In five cases less than $5-10 \%$ of cells were neoplastic and therefore immunohistochemistry was also carried out on paraffin wax sections.

In the 20 cases for which frozen and paraffin wax sections were stained with both antibodies, the same results were obtained in both specimen types in all but six cases (table 1). On analysis of frozen sections, all six were negative with PAb 1801, while four became positive on staining with the same antibody on paraffin wax sections. When BP53-12-1 was used, two 

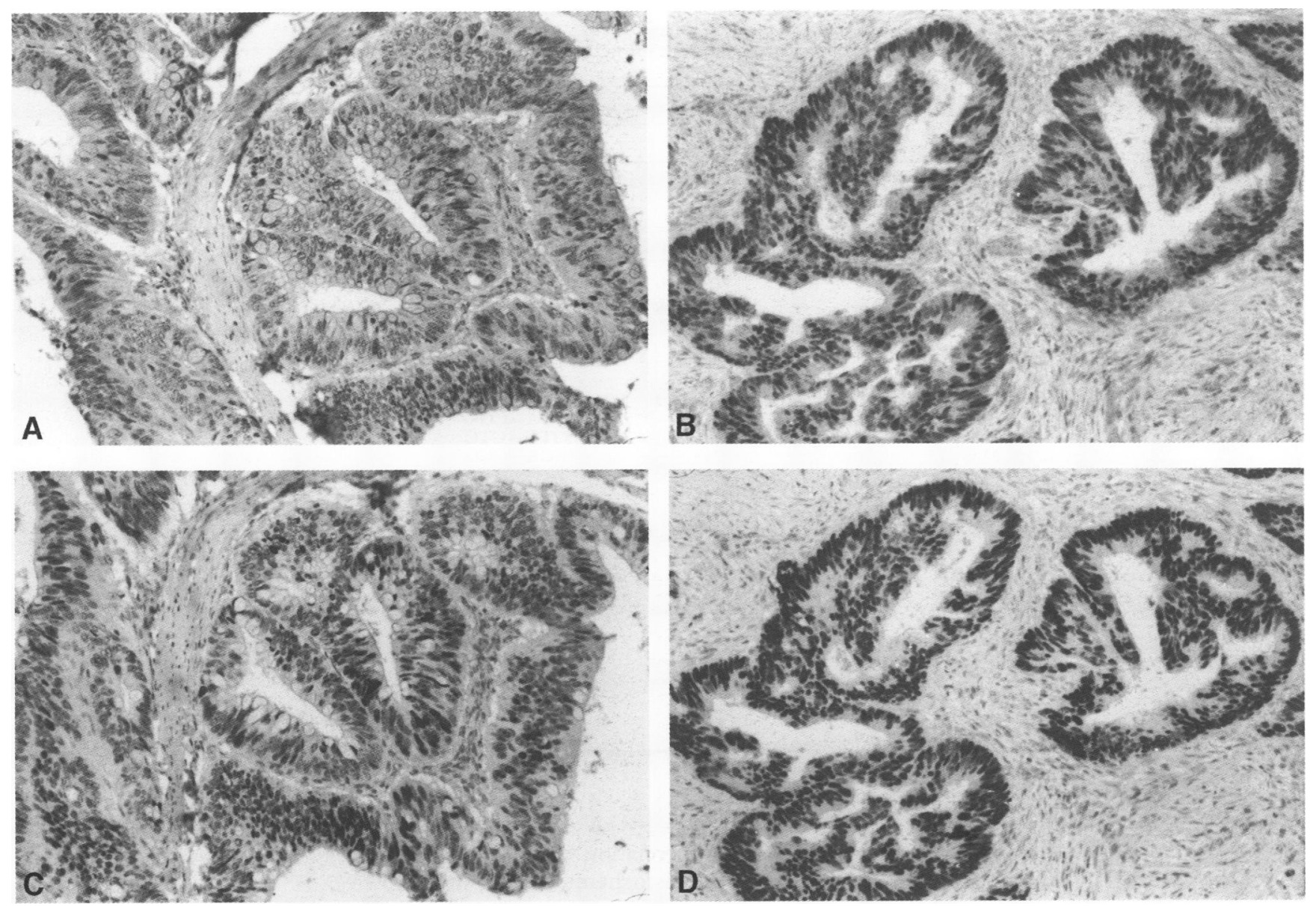

Figure 1 Immunohistochemical detection of p53 protein by monoclonal antibodies PAb 1801 ( $A$ and B) and BP53-12-1 (C and D) on formalin fixed, paraffin wax embedded tissue sections of two different cases $(\times 185)$.

cases were negative on analysis of the frozen sections while all six were positive on examination of paraffin wax sections. All six cases, therefore, were finally regarded as having p53 protein accumulation for concordance analysis. In the case of the two negative results on frozen sections (PMV, CE) with both antibodies, this result was probably because the material was unsuitable as both antibodies gave a positive result on paraffin wax sections and a large number of tumour cells was present. In the other cases the BP53-12-1 antibody seemed to be more sensitive.

By comparing the immunohistochemical patterns of nuclear reactivity, evaluated as both the percentage of positive cells/total number of neoplastic cells, and the intensity of staining, some differences between the two antibodies emerged. In general, when more than $75 \%$ of the cells were positive, the antibodies showed a similar pattern (25 cases were +++ with both antibodies); however, cases that scored + or ++ with PAb 1801 often scored +++ with BP53-12-1 (15 cases had a higher score with BP-53-12-1). Moreover, BP53-12-1 generally showed a cleaner and more intense staining reaction (fig 1 ).

\section{P53 GENE MUTATIONS}

Tumour samples from all 94 cases of colorectal carcinoma were screened by PCR-SSCP analysis for mutations within exons $5-8$ of the p53 gene, and compared with normal tissue from the same patient. A non-wild-type migration pattern was found in 30 cases, 27 of which showed also p53 protein accumulation. Subsequent sequence analysis confirmed the occurrence of a mutation in 29 cases and showed a polymorphism at codon 213 in one. Moreover, this same polymorphism was found in one of the above 29 cases, in association with a mutation in the same exon. Eleven cases showed mutations in exon 5 , four in exon 6 , eight in exon 7 , and six in exon 8 ; the types of mutations identified are described in table 2 . In summary, there were $17 \mathrm{G}$ to $\mathrm{A}$ or $\mathrm{C}$ to $T$ transitions, four $A$ to $G$ transitions (two polymorphisms), seven transversions, two deletions, and one duplicating insertion. SSCP and sequence analysis of two representative cases are shown in fig 2 .

\section{CORRELATION BETWEEN PCR-SSCP AND} IMMUNOHISTOCHEMICAL FINDINGS

The concordance of results between immunohistochemistry and PCR-SSCP was $72.0 \%$ (both positive in 27 and both negative in 40 cases). Twenty four cases were positive on immunohistochemistry but negative on SSCP analysis, while only two cases were positive on SSCP analysis and negative on immunohistochemistry (table 3 ). The case showing the polymorphism at codon 213 and a negative result on immunohistochemistry was excluded 
Table 2 Nuclear accumulation of p53 protein in cases with $\mathrm{p} 53$ gene mutations

\begin{tabular}{|c|c|c|c|c|c|}
\hline \multirow[b]{3}{*}{ Case } & \multicolumn{3}{|c|}{ p53 mutations } & \multirow{2}{*}{\multicolumn{2}{|c|}{$\frac{p 53 \text { accumulation }}{\text { Immunohistochemistry }}$}} \\
\hline & \multirow{2}{*}{$\begin{array}{l}\text { SSCP } \\
\text { Exon }\end{array}$} & \multicolumn{2}{|l|}{ Sequence } & & \\
\hline & & Codon & Base change & $P A b 1801$ & BP53-12-1 \\
\hline 1. A.A. & 5 & 157 & $\mathrm{GTC} \rightarrow \mathrm{CTC}$ & + & +++ \\
\hline 2. S.E. & 5 & 161 & $\mathrm{GCC} \rightarrow \mathrm{ACC}$ & $+t+$ & $+t+$ \\
\hline 3. V.I. & 5 & 181 & $\mathrm{CGC} \rightarrow \mathrm{CAC}$ & ++ & +++ \\
\hline 4. G.A. & 5 & 132 & $\mathrm{AAG} \rightarrow \mathrm{AGG}$ & + & + \\
\hline 5. B.A. & 5 & 143 & GTG $\rightarrow$ ATG & $++t$ & +++ \\
\hline 6. G.C. & 5 & 175 & $\mathrm{CGC} \rightarrow \mathrm{CAC}$ & ++ & $+t+$ \\
\hline 7. M.G. & 5 & 161 & $\mathrm{GCC} \rightarrow \mathrm{ACC}$ & ++ & +++ \\
\hline 8. V.R. & 5 & $157-158$ & Insert GTC CGC & +++ & +++ \\
\hline 9. A.A. & 5 & 165 & $\mathrm{CAG} \rightarrow \mathrm{TAG}$ & - & - \\
\hline 10. B.D. & 5 & 157 & $\mathrm{GTC} \rightarrow \mathrm{CTC}$ & $t+t$ & $+t+$ \\
\hline 11. M.P. & 5 & 141 & $\mathrm{TGC} \rightarrow \mathrm{TAC}$ & ++ & +++ \\
\hline 12. P.O. & 6 & 191 & 3 bp deletion & +++ & $t+t$ \\
\hline 13. B.L. & 6 & $208-213$ & $16 \mathrm{bp}$ deletion & $++t$ & $++t$ \\
\hline 14. S.P. & 6 & $\begin{array}{l}213 \\
216\end{array}$ & $\begin{array}{l}\mathrm{CGA} \rightarrow \mathrm{CGG}^{*} \\
\mathrm{GTG}^{*} \rightarrow \mathrm{CTG}^{-}\end{array}$ & ++ & +++ \\
\hline 15. M.G. & 6 & 213 & CGA $\rightarrow \mathrm{CGG}^{*}$ & - & - \\
\hline 16. S.N. & 6 & 220 & $\mathrm{TAT} \rightarrow \mathrm{TGT}$ & + & +++ \\
\hline 17. B.R. & 7 & 249 & $\mathrm{AGG} \rightarrow \mathrm{AGT}$ & ++ & ++ \\
\hline 18. L.R. & 7 & 248 & $\mathrm{CGG} \rightarrow \mathrm{TGG}$ & $++t$ & $++t$ \\
\hline 19. C.A. & 7 & 245 & $\mathrm{GGC} \rightarrow \mathrm{AGC}$ & ++ & $++t$ \\
\hline 20. L.O. & 7 & 237 & ATG $\rightarrow$ ATT & ++ & $+t+$ \\
\hline 21. S.U. & 7 & 244 & $\mathrm{GGC} \rightarrow \mathrm{TGC}$ & - & +++ \\
\hline 22. T.D. & 7 & 238 & $\mathrm{TGT} \rightarrow \mathrm{TAT}$ & +++ & +++ \\
\hline 23. R.L. & 7 & 248 & $\mathrm{CGG} \rightarrow \mathrm{TGG}$ & +++ & +++ \\
\hline 24. C.L. & 7 & 244 & $\mathrm{GGC} \rightarrow \mathrm{GAC}$ & +++ & $++t$ \\
\hline 25. F.G. & 8 & 282 & $\mathrm{CGG} \rightarrow \mathrm{TGG}$ & + & ++ \\
\hline 26. L.T. & 8 & 282 & $\mathrm{CGG} \rightarrow \mathrm{TGG}$ & +++ & $++t$ \\
\hline 27. M.L. & 8 & 282 & $\mathrm{CGG} \rightarrow \mathrm{TGG}$ & +++ & +++ \\
\hline 28. B.R. & 8 & 276 & $\mathrm{GCC} \rightarrow \mathrm{ACC}$ & +++ & +++ \\
\hline 29. A.A. & 8 & 278 & $\mathrm{CCT} \rightarrow \mathrm{ACT}$ & +++ & $++t$ \\
\hline 30. H.W. & 8 & 306 & $\mathrm{CGA} \rightarrow \mathrm{TGA}$ & - & - \\
\hline
\end{tabular}

* Polymorphism; bp = base pairs.

from concordance analysis. No correlation was observed between the immunohistochemical score and the presence and type of mutation.

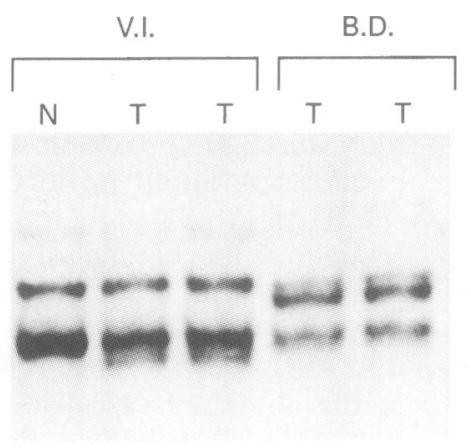

exon 5
Table 3 Relation between p53 accumulation detected by immunohistochemistry and p53 mutations by SSCP analysis in colorectal carcinomas

\begin{tabular}{llcl}
\hline & \multicolumn{2}{l}{ Immunohistochemistry } & \\
\cline { 2 - 3 } & Positive & Negative & Total \\
\hline SSCP positive & $27(29 \%)$ & $2(2 \%)$ & $29(31 \%)$ \\
SSCP negative & $24(26 \%)$ & $40(43 \%)$ & $64(69 \%)$ \\
Total & $51(55 \%)$ & $42(45 \%)$ & $93(100 \%) *$ \\
\hline
\end{tabular}

* The case showing the polymorphism only was excluded from concordance analysis.

\section{Discussion}

In this study 94 primary colorectal carcinomas were evaluated for $\mathrm{p} 53$ protein expression and p53 gene mutations by immunohistochemistry and PCR-SSCP. At present, the use of immunohistochemistry to detect p53 mutations is still controversial, as accumulation of p53 protein might also occur through stabilisation by mechanisms other than mutation. That accumulation of $\mathrm{p} 53$ protein is an index of cell cycle deregulation is still a matter of debate. In this regard, it is important to highlight some methodological aspects of both the immunohistochemical and PCR-SSCP assays.

In immunohistochemistry there are no set standards for the specificity or sensitivity of the different antibodies available, nor the minimal percentage of positive cells required to score a section as positive. As the detection of a given amount of antigen by immunohistochemistry is influenced by the affinity and concentration of the antibody, as well as by the sensitivity of the detection system, it is imperative that the conditions used are defined for diagnostic and prognostic purposes. In our experience, the use of two different monoclonal antibodies optimally defines the specificity of the reactivity
Figure 2 Upper panel: SSCP analysis in normal $(N)$ and tumour (T) samples of two patients. Lower panel: Sequencing of tumour sample from patient V.I. showing a $G$ to $A$ transition at codon 181 and in patient B.D. showing a $G$ to $C$ transversion at codon 157. 
observed. In fact, while the nuclear staining was confirmed by both antibodies in the same cases (discordant results were an occasional finding) in the present study, cytoplasmic reactivity was a rare finding and could be interpreted as an artefact (rather than a real accumulation of $\mathrm{p} 53$ protein outside the nucleus).

It is important to establish the minimum number of stained neoplastic cells needed to regard a tumour sample as positive. Because the number of stained cells required for a positive result varies from study to study, the results obtained by different groups are difficult to compare. Indeed, for some workers one or a few positive cells are indicative of a positive sample, while we and others ${ }^{11519}$ require a minimum of $5-10 \%$ stained cells for a positive result to avoid the possibility of false positive reactions due to background staining or artefacts. In the present study, many tumour samples which scored as + or ++ on staining with PAb 1801 antibody became ++ or +++ with BP53-12-1. Thus, the phenotypic pattern of the tumour could depend on the sensitivity and specificity of the antibody used, and therefore correlation of the phenotypic pattern with the presence and type of mutation, or even with patient prognosis and outcome would be arbitrary.

A comparison of PCR-SSCP and immunohistochemical findings showed concordant results in $72.0 \%$ of our cases. In particular, $27(93.1 \%)$ of the 29 cases showing a p53 gene mutation were also positive for p53 protein accumulation on immunohistochemistry, while $24(37.5 \%)$ of the 64 cases without mutations were positive on immunohistochemistry. In 26 $(28.0 \%)$ cases the immunohistochemical and SSCP results were discordant; negative immunohistochemistry/positive SSCP in two, and positive immunohistochemistry/negative SSCP in 24. On sequencing, the two cases with a p53 mutation on SSCP analysis and no immunohistochemical staining had a nonsense mutation which resulted in the substitution of a coding triplet by a stop signal at codons 165 (exon 5) and 306 (exon 8), respectively. In both cases, the encoded protein was truncated at the C-terminal region, and lacked the nuclear localisation signal I (residues 312-323) essential for its transport to the nucleus. ${ }^{2526} \mathrm{Se}$ quence analysis of DNA from normal and tumour tissue in the case with the polymorphism at codon 213 in exon 6 showed a silent CGA to CGG transition (arginine to arginine), and the normal $\mathrm{p} 53$ protein produced did not accumulate in the cell. ${ }^{27}$ As the SSCP screening method does not distinguish polymorphisms from mutations, sequence analysis is necessary to clarify the significance of the altered electrophoretic pattern.

Accumulation of $\mathrm{p} 53$ protein with no evidence of gene mutation may either reflect an accumulation of a non-mutated protein, or a false negative SSCP result (the p53 gene is mutated but not detected by the SSCP technique). The sensitivity of SSCP analysis is still a matter of debate; not only does it depend on the experimental conditions (that is, tem- perature, ionic strength and the presence or absence of glycerol), but also on the length of the amplified fragment being analysed. ${ }^{28}$ Sheffield $e t a l^{29}$ reported that SSCP sensitivity dramatically decreases with increasing fragment size; the percentage of single base substitutions detected by SSCP is $90 \%$ when the amplified fragment is 135 base pairs (bp), and $70 \%$ when it is $200 \mathrm{bp}$. When the fragment size exceeds $300 \mathrm{bp}$, sensitivity is even lower $(67 \%) .{ }^{30}$ As the length of the amplified products we analysed was $245 \mathrm{bp}$ for exon $5,184 \mathrm{bp}$ for exon 6,110 bp for exon 7, and 213 bp for exon 8 , SSCP sensitivity for exons 5 and 8 might have been less than $70 \%$. With regard to the experimental conditions, Condie et $a l^{31}$ reported that SSCP detected $90 \%$ of the p53 gene mutations when the electrophoretic run was carried out at $4^{\circ} \mathrm{C}$, with $0.5 \times \mathrm{TBE}$, but its sensitivity decreased to $55 \%$ under different analytical conditions (room temperature, 5\% glycerol).

In a comparison of 52 different mutations, Moyret et $a l^{32}$ found that SSCP consistently failed to detect mutations in two regions, the first of which was localised between codons 151 and 154, and the other between codons 272 and 273. Interestingly, samples from four of the five cases that escaped SSCP screening were of colon carcinoma. We did not observe any alterations on SSCP analysis which, after sequencing, revealed a mutation in these regions.

Although our study focused on exons 5 to 8 , where the majority of the mutations are thought to be localised, ${ }^{133}$ mutations in other exons could account for some negative SSCP cases. Indeed, recent studies by Greenblatt et $a l^{34}$ and Hartmann et $a l^{35}$ indicated that $13 \%$ and $22 \%$, respectively, of the p53 gene mutations reported fell outside exons 5-8. A false negative SSCP result may also occur when the tumour is not sufficiently represented in the tissue from which the DNA is extracted. Morphological analysis of our discordant cases revealed that at least five samples were composed of less than $5-10 \%$ tumour cells.

Accumulation of wild-type p53 protein can be detected by immunohistochemistry because the antibodies are not specific for the mutant form, and the wild-type protein can be stabilised by interacting with other nuclear, cellular and viral proteins. ${ }^{36-38}$ In any case, binding with these proteins results in the functional inactivation of the p53 gene. Moreover, concentrations of wild-type p53 protein in the cell may also increase either in response to continuous genetic damage, which may occur more frequently in tumour cells than in normal tissue, or because another component of the p53 suppression pathway (for example, WAF1/ cip 1) is altered. ${ }^{39}$

In general, the environment (mutations, protein interactions, or stimuli derived from activation of oncogenes, such as $c-m y c$ and ras, as reported by $\mathrm{Lu}$ et $a l^{40}$ ) seems to be the determining factor for accumulation of p53 protein at high concentrations. ${ }^{41}$ This accumulation results from the loss of rapid p53 protein turnover and might be a signal of its 
altered function; loss of function of this cell cycle checkpoint gene could contribute to genetic instability and tumorigenesis. This observation is supported by the studies of Donehower et $a l^{42}$ in $\mathrm{p} 53$ gene deficient mice, in which the loss of normal p53 protein was shown to predispose the animals to neoplastic disease.

The search for p53 gene mutations by molecular assays is important for defining the functional alterations that derive from the different mutations. In this regard, it might be advisable to study all of the exons of the p53 gene. Accumulation of $\mathrm{p} 53$ protein may be more meaningfully regarded as an index of the functional status of the $\mathrm{p} 53$ gene, rather than an index of gene mutation, providing the analytical procedures are standardised and the appropriate controls are used.

In our opinion, immunohistochemistry is a simple and rapid method for the evaluation of p53 protein expression as a prognostic marker in many tumours. Its association with molecular analysis of the $\mathrm{p} 53$ gene might provide a more precise definition of the changes/mutations resulting in the accumulation of the p53 protein.

We thank Mrs. Patricia Segato for help in preparing the manuscript; Emma D'Andrea for critical discussion; and Catia Cavestro, Dina Pozza and Rossana Trevisan for technical assistance. This work was supported in part by a grant from the Associazione Italiana per la Ricerca sul Cancro (AIRC), Milano, and also in part from the Regione Veneto, Ricerca Sanitaria Finalizzata, Italy

1 Hollstein M, Sidransky D, Vogelstein B, Harris CC. p53 mutations in human cancers. Science 1991;253:49-53.

2 Kastan MB, Onyekwere O, Sidransky D, Vogelstein B, Craig R. Participation of $\mathrm{p} 53$ protein in the cellular response to DNA damage. Cancer Res 1991;51:6304-11.

3 Prokocimer M, Rotter V. Structure and function of p53 in normal cells and their aberrations in cancer cells: projection on the hematologic cell lineages. Blood 1994;84: 2391-411.

4 Sarnow P, Ho YSH, Williams J, Levine AJ. Adenovirus E1b$58 \mathrm{kd}$ tumor antigen and SV40 large tumor antigen are physically associated with the same $54 \mathrm{kd}$ cellular protein in transformed cells. Cell 1982;28:387-94.

5 Wynford-Thomas D. p53 in tumor pathology: can we trust immunocytochemistry? f Pathol 1992;166:329-30.

6 Hall PA, Lane DP. p53 in tumor pathology: can we trust immunohistochemistry? - Revisited! f Pathol 1994;172: $1-4$

7 Orita M, Suzuky Y, Sekita T, Hayashi K. Rapid and sensitive detection of point mutations and DNA polymorphisms using the polymerase chain reaction. Genomics $1989 ; 5$ : 874-9.

8 Cripps KJ, Purdie CA, Carder PJ, White S, Komine K, Bird CC, et al. A study of stabilisation of p53 protein versus point mutation in colorectal carcinoma. Oncogene 1994;9:2739-43

9 Dix B, Robbins P, Carrello S, House A, Iacopetta B. Comparison of $\mathrm{p} 53$ gene mutation and protein overexpression in colorectal carcinomas. $\mathrm{Br} 7$ Cancer 1994;70:585-90.

10 Cordon-Cardo C, Dalbagni G, Saez GT, Oliva MR, Zhang Z-F, Rosai J, et al. p53 mutations in human bladder cancer: genotypic versus phenotypic patterns. Int 7 Cancer 1994 56:347-53.

11 Esrig D, Spruk CH III, Nichols PW, Chaiwun B, Steven $\mathrm{K}$, Groshen S, et al. p53 nuclear protein accumulation correlates with mutations in the p53 gene, tumor grade, and stage in bladder cancer. Am f Pathol 1993;143:138997.

12 Umekita Y, Kobayashi K, Saheki T, Yoshida H. Nuclear accumulation of $\mathrm{p} 53$ protein correlates with mutations in the p53 gene on archival paraffin-embedded tissues of the p53 gene on archival paraffin-embedded tissues of

13 Allred DC, Clark GM, Elledge R, Fuqua SAW, Brown RW, Chamness GC, et al. Association of p 53 protein expression with tumor cell proliferation rate and clinical outcome in node-negative breast cancer. 7 Natl Cancer Inst 1993;85 $200-5$.

14 Hong SI, Hong WS, Jang JJ, Lee DS, Cho NS, Jung ME et al. Alterations of p53 gene in primary gastric cancer tissues. Anticancer Res 1994;14:1251-6.
15 Scarpa A, Capelli P, Mukai K, Zamboni G, Oda T, Iacono $\mathrm{C}$, et al. Pancreatic adenocarcinomas frequently show $\mathrm{p} 53$ gene mutations. Am f Pathol 1993;142:1534-43.

16 Baas IO, Mulder J-WR, Offerhaus GJA, Vogelstein B, Hamilton R. An evaluation of six antibodies for immunohistochemistry of mutant p53 gene product in archival colorectal neoplasms. F Pathol 1994;172:5-12.

17 Kikuchi-Yanoshita R, Konishi M, Ito S, Seki M, Tanaka K, Maeda Y, et al. Genetical changes of both p53 alleles associated with the conversion from colorectal adenoma to early carcinoma in familial adenomatous polyposis and non-familial

18 Bertorelle R, Esposito G, Del Mistro A, Belluco C, Nitti $\mathrm{D}$, Lise M, Chieco-Bianchi L. Association of $\mathrm{p} 53$ gene and protein alterations with metastases in colorectal cancer. $\mathrm{Am}$ f Surg Pathol 1995;19:463-71.

19 Banks L, Matlashewski G, Crawford L. Isolation of humanp53-specific monoclonal antibodies and their use in the studies of p53 expression. Eur F Biochem 1986;1 159:529-34.

20 Bartek J, Bartkova J, Vojtesek B, Staskova Z, Lukas J, Rejthar $\mathrm{A}$, et al. Aberrant expression of the p53 oncoprotein is a common feature of a wide spectrum of human malignancies. Oncogene 1991;6:1699-703.

21 Shi S-R, Key ME, Kalra KL. Antigen retrieval in formalinfixed, paraffin-embedded tissues: an enhancement method for immunohistochemical staining based on microwave oven heating of tissue sections. F Histochem Cytochem 1991; 39:741-8.

22 Cuevas EC, Bateman AC, Wilkins BS, Johnson PA, Williams $\mathrm{JH}$, Lee AHS, et al. Microwave retrieval in immunohistochemistry: a study of antibodies. $\mathcal{F}$ Clin Pathol 1994; 47:448-52.

23 Levi S, Urbano-Ispizua A, Gill R, Thomas DM, Gilbertson $\mathrm{J}$, Foster $\mathrm{C}$, et al. Multiple K-ras codon 12 mutations in cholangiocarcinomas demonstrated with a sensitive polymerase chain reaction technique. Cancer Res 1991;51: 3497-502.

24 Sanger F, Nicklen S, Coulson AR. DNA sequencing with chain terminating inhibitors. Proc Natl Acad Sci USA 1977; 74:5463-7.

25 Addison C, Jenkins JR, Sturzbecher HW. The p53 nuclear localization signal is structurally linked to a p $34 \mathrm{cdc} 2$ kinase motif Oncogene 1990;5:423-6.

26 Shaulsky G, Goldfinger N, Ben-Ze'Ve A, Rotter V. Nuclear accumulation of $\mathrm{p} 53$ protein is mediated by several nuclear accumulation of $\mathrm{p} 53$ protein is mediated by several nuclear Cell Biol 1990;10:6565-77.

27 Carbone D, Chiba I, Mitsudomi T. Polymorphism at codon 213 within the p53 gene. Oncogene 1991;6:1691-2.

28 Hayashi K, Yandell DW. How sensitive is PCR-SSCP? Hum Mutat 1993;2:338-46.

29 Sheffield VC, Beck JS, Kwitek AE, Sandstrom AW, Stone EM. The sensitivity of single-strand conformation polymorphism analysis for the detection of single base substitutions. Genomics 1993;16:325-32.

30 Hayashi K. PCR-SSCP: a simple and sensitive method for detection of mutations in the genomic DNA. PCR Methods Appl 1991;1:34-8.

31 Condie A, Eeles R, Borresen A-L, Coles C, Cooper C, Prosser J. Detection of point mutations in the p53 gene: comparison of single-strand conformation polymorphism, constant denaturant gel electrophoresis, and hydroxylamine and osmium tetroxide techniques. Hum Mutat 1993;2:58-66

32 Moyret C, Theillet C, Laurent-Puig P, Moles J-P, Thomas G, Hamelin R. Relative efficiency of denaturing gradient gel electrophoresis and single strand conformation polymorphism in the detection of mutations in exons 5 to 8 of the p53 gene. Oncogene 1994;9:1739-43.

33 Caron De Frommentel C, Soussi T. TP53 tumor suppressor gene: a model for investigating human mutagenesis. Genes gene: a model for investigating hum

34 Greenblatt MS, Bennet WP, Hollstein M, Harris CC. Mutations in the p53 tumor suppressor gene: clues to cancer etiology and molecular pathogenesis. Cancer Res 1994;54: 4855-78.

35 Hartmann A, Blaszyk H, McGovern RM, Schroeder JJ, Cunningham J, De Vries EMG, et al. p53 gene mutations inside and outside of exons 5-8: the patterns differ in breast and other cancers. Oncogene 1995;10:681-8.

36 Momand J, Zambetti GP, Olson DC, George D, Levine AJ. The mdm-2 oncogene product forms a complex with the p53 protein and inhibits p53-mediated transactivation. p53 protein and inhibits

37 Sheffner M, Werness BA, Huibregtse JM, Levine AJ, Howley PM. The E6 oncoprotein encoded by human papilloma PM. The E6 oncoprotein encoded by human papilloma
virus type 16 and 18 promotes degradation of p53. Cell virus type 16 and

38 Levine AJ, Momand J, Finlay CA. The p53 tumour suppressor gene. Nature 1991;351:453-6.

39 El-Deiry WS, Tokino T, Velculescu VE, Levy DB, Parsons $\mathrm{R}$, Trent JM, et al. WAF 1 , a potential mediator of $\mathrm{p} 53$ tumor suppression. Cell 1993;775:817-25.

40 Lu X, Park SH, Thompson TC, Lane DP. ras-induced hyperplasia occurs with mutation of $\mathrm{p} 53$, but activated ras and myc together can induce carcinoma without $\mathrm{p} 53$ mutation. Cell 1992;70:153-61.

41 Lane DP. The regulation of p53 function: Steiner Award Lecture. Int $\mathcal{F}$ Cancer 1994;57:623-7.

42 Donehower LA, Harvey M, Slagle BL, McArthur MJ, Montgomery CA Jr, Butel JS, et al. Mice deficient for $\mathrm{p} 53$ are developmentally normal but susceptible to spontaneous tumours. Nature 1992;356:215-21. 